\title{
Roel Westrick, Jeroen van der Weide: Party autonomy in international property law
}

Sellier European Law Publishers, 2011

\author{
Juergen G. Backhaus
}

Published online: 18 December 2011

(C) Springer Science+Business Media, LLC 2011

Sellier European Law Publishers is a small Munich based imprint publishing primarily conference proceedings volumes in comparative European law.

The leitmotif of the volume European private law: unity in diversity is the postulation of a convergence theory, which may come true due to the activities of the European Court of Justice.

Partly autonomy in international Property Law refers the proceedings of an international conference with 22 participating universities held at Erasmus Law School in May 2010.

The volumes are well produced, the publication is timely a law and economics perspective, although called for by the topics, could not be detected.

J. G. Backhaus ( $₫)$

Public Finance and Fiscal Sociology, University of Erfurt, Nordhäuser Strasse 63, 99089 Erfurt, Germany

e-mail: juergen.backhaus@uni-erfurt.de 